\title{
Representation Of Traditional Buton Events In Fiction Works By Wa Ode Wulan Ratna: a Study Of New Historicism
}

\author{
Nurul Baiti Rohmah ${ }^{1 *}$, Uman Rejo ${ }^{2}$ \\ Institut Agama Islam Negeri Tulungagung,Jalan Mayor Sujadi Timur No. 46 Tulungagung \\ Provinsi Jawa Timur, Indonesia ${ }^{1}$ \\ Universitas Timor,Jalan Km 9 Kelurahan Sasi, Kefamenanu, Kab. Timor Tengah Utara, \\ Provinsi Nusa Tenggara Timur (NTT), Indonesia ${ }^{2}$ \\ \{nurulbaitirohmah@iain-tulungagung.ac.id ${ }^{1}$,umanrejo@unimor.ac.id\}
}

\begin{abstract}
This research aims to explore and describe the traditional representation of Buton in fiction by Wa Ode Wulan Ratna. To be able to realize it, then the literary approach used is a new historicism approach. This approach was first introduced by Stephen Greenblat of America. In its implementation, this approach positioned literary texts within the framework of non-literary texts. This approach emphasizes the fascination between literary text and the various socio-cultural potentials that surround it. In this case, the fictional text by Wa Ode Wulan Ratna will be positioned within the framework of the traditional socio-cultural traditions of the Buton people located in Southeast Sulawesi. The research method used is a qualitative descriptive method. The results showed as follows. First, the socio-cultural practice of the Traditional Buton tradition in the fictional Wa Ode Wulan Ratna experienced the opposition of the main female characters. The woman's main character's relationship with her lover is not supported by her parents because she is from an erred community. Second, the social understanding that comes against the backdrop of the Traditional Buton tradition in fiction is mentioned to test the virginity of the main female character before the onset of marriage. Third, the ideology supported by the fictional text associated with the traditional traditions of the Buton people is a feminist ideology against the local traditions of the local community.
\end{abstract}

Keywords: representation; local traditions; opposition; new historicism; feminist ideology

\section{Introduction}

Wa Ode Wulan Ratna's fiction "La Runduma" is one of the fictional products of Indonesian female literature that raises the issue of the local culture of the Buton people in Southeast Sulawesi. This fiction was first published in the Sunday edition of Republika in December 2006. Furthermore, this fiction was an anthology by Korrie Layun Rampan and placed in chapter 2 in his book titled Antologi Apresiasi Sastra Indonesia Modern (2013), 
which in this book is distinguished into five chapters, such as chapter 1 poetry, chapter 2 short story, chapter 3 essay, chapter 4 drama, and chapter 5 fragment of the novel. There is a special consideration, why this short story by Wa Ode Wulan Ratna is included in her anthology Korrie Layun Rampan. This particular reason is conveyed in the "Introduction" section of this anthology, which is because this fictional text has been known to get many awards in every short story writing event in all corners of the country.

In her short autobiography, Wa Ode Wulan Ratna is a female poet born in Jakarta on August 23, 1984. She was the sixth of seven children and a descendant of nobility. As seen in the noble title used in front of her name, Wa Ode. Wa Ode is a noble title in the Buton kingdom derived from the father. The existed of this title, named that Wa Ode Wulan Ratna still has the titian descendants of nobles or sultans from Buton.

Wa Ode Wulan Ratna studied Indonesian Literature at State University of Jakarta (UNJ). Some of the achievements related to creative writing that she has achieved, among them the Creative Writing Institute (CWI) Contest in 2005, Contest of Malay Theme Short Story by Riau Arts Council (DKR) in 2005, Krakatau Award Short Story Contest by Lampung Arts Council (DKL) in 2005, Equatorial Literature Kusala for talented young writers category in 2008, Literature selected in Ubud Writers and Readers Festival, Equatorial Literary Award for young writers in 2008, and the third winner of the 2005 human rights-themed short story contest by the Swiss Embassy and The Pen Circle. Recently, Wa Ode Wulan Ratna is a lecturer in creative writing at Multimedia Nusantara University of Jakarta.

The purpose of this paper is to explore and describe the traditional representation of Buton in the fiction of Wa Ode Wulan Ratna. The fiction titled "La Runduma" will be presented using a new historicism approach. According to Greenblatt (Greenblatt, 2005), the basic assumption of this approach is the reciprocal influence between man and his culture. People are formed and co-shape the culture in which they live. Also, through this approach, it may be considered the relationship between the text and the context that includes the social practices that the text confirms, the social understanding underlying the text, the freedom of thought reflected in the text, and the broader social structure or implied ideology supported in the text (Gallagher \& Greenblatt, 2000). Budianta (Budianta, 2006) added that this approach of looking at history or the world that literary works are using is not just a coherent background and that blends with accessible transparency. The historical reality is not singular and absolute, but consists of a wide variety of versions full of contradictions, disconnects, plurality, and diversity. Thus, the relationship between history and literature is the intertextuality between different texts, both fiction and factual, reproduced over the same or different periods.

\section{Methods}

This research was presented using qualitative descriptive methods. This method is very effectively used to explore and describe the traditional representation of Buton in the fiction of Wa Ode Wulan Ratna. The data source used is distinguished into two, which are primary and secondary data sources. The primary data source is the fiction "La Runduma" by Wa Ode Wulan Ratna. This fiction is contained in an anthology compiled by Korrie Layun Rampan, published in 2013 by the publisher Narasi situated in Yogyakarta, and spotted on pages 160 167. Secondary data sources are the data that supported the main focus of this article. The supporting data are books that discuss the socio-cultural traditions of Buton tradition, other research reports, as well as scientific articles in the form of journal articles or articles 
published in various media. Because the method used is qualitative descriptive, the data used in the form of words, sentences, and quotations contained in the data sources.

The data collection techniques used, which are library techniques, record techniques, and interview techniques. The interview techniques used in this study are unstructured and performed in an informal way. This aims to link between text and context that supports focus language. Furthermore, to obtain the validity of the data, it will be triangulated data. In data analysis, the technique used is the content analysis technique. This analysis technique is very suitable for use because it can provide an understanding and explanation of the content analyzed. How to use this technique was by deciphering the focus of the discussion eplained in this paper objectively, systemically, in detail, and in-depth. This is done with the mission so that the representation of the traditional traditions of Buton in this fiction can be conveyed optimally. First, to analyzed the socio-cultural practices of the Buton tradition in the fiction of Wa Ode Wulan Ratna. Second, to examine the social understanding that is against the backdrop of the traditional traditions of Buton in the fiction by Wa Ode Wulan Ratna. Third, analyzing the ideology supported by this fictional text relates to the traditional traditions of Buton. After using content analysis techniques, the next step is to convey the results and the language in the form of scientific articles, which are then published in the proceedings of this international seminar.

\section{Results and Discussions}

\subsection{Social-Cultural Practice of Buton Indigenous Traditions in Fiction}

The socio-cultural practices found in Wa Ode Wulan Ratna's fiction can be classified into several things. First, it is related to social standing or social stratification. This is seen in the relationship between the main character named La Runduma and Johra. Johra's father Maulidun did not approve of the relationship, as La Runduma did not have an equal position. Johra's father, Maulidun, was a well-respected man in the Palace of Buton. Second, a parent's social actions force their child's will. In this case, it appears to Johra that her father forced her to marry a man equal to her. Although in this fiction, it is not mentioned and portrayed the man who was his father's choice. Also, Maulidun also forced Johra to follow the traditional Buton tradition named Posuo.

Posuo is a traditional Buton tradition located in Southeast Sulawesi. Posuo is a ritual or transitional ceremony for girls who have entered puberty (Alifuddin, 2015), namely from teenage girls (labuabua) to girl status (kalambe) (Rampan, 2013). According to Alifudin (Alifuddin, 2015), this ritual or ceremony for a girl is carried out for $8 \times 24$ hours, carried out by locking the girl up during the appointed period to provide an experience about community life, family, and various ethics that must be adhered to by a girl who has entered puberty. Some people refer to this ritual as a "pingitan". As the true daughter of the Buton people, this kind of ritual must be followed.

Third, Johra made an appointment with La Runduma to come and take her away at the post-match event. Johra was tormented with every session of this posuo activity. In its implementation, Johra felt tormented by having to be locked up in a cramped, stuffy, humid room (suo), with no lighting at all. Also, the room was filled with seven other girls. Within $8 \mathrm{x}$ 24 Hours, Johra must be in this room. Johra learns that someone is following posuo rituals and tarnishes this ritual. Johra is afraid of something happening to her father's drum. In this posuo ritual tradition, drums have a very meaningful meaning to the indigenous peoples of Buton. When the drum brakes it indicates that the girl is no longer a virgin. 
Fourth, the drum that Johra's father had broken. The organizers of the posuo panicked about the broken drum. Fifth, La Runduma fulfilled his promise and went to Johra as Johra queued with the other pasuos to bathe. Finally, Johra left with La Runduma leaving the place. Sixth, Johra's father was angry at La Runduma for carrying Johra's run. Johra was accused of being no longer a virgin by posuo organizers and her father. This was a form of injustice that Johra experienced during the ritual. Johra is still a virgin as she says, but this customary ritual says otherwise, due to the rupture of the drum that her father, many people around her accused her of not being a virgin anymore.

\subsection{A Social Understanding That Backgrounds Buton Traditional Traditions in Fiction}

In Wa Ode Wulan Ratna's fiction "La Runduma", the main cause of the Buton tradition in the form of posuo rituals or ceremonies was held as follows. As part of the Buton Palace and the true Buton community, this ritual or ceremony must be held. According to Fariki (Fariki, 2009), the Buton community considered that the posuo ritual is part of the parental obligation towards their daughter. Parents feel guilty if their daughter hasn't been isolated. Therefore, parents and close family will seek that a daughter should be dipping even though she will not be married. The obligation of women to perform this posuo ritual that is not reserved for men showed that attention to girls is greater than those men. Knowledge or teachings obtained during the secluded were expected to be a provision for women before entering the ark of the household (Fariki, 2009).

About function, Adilia and Said (Adilia \& Said, 2019) were tried to conclude it below. First, the posuo ritual is used as a means of transitioning status, namely from a teenage girl (labuabua) to girl status (kalambe). Second, the used of posuo was cleansing or purification the soul for women. Third, it was essential in the sense of education for women before living in the household ark. In its implementation, this posuo ritual is not only as a medium of ritual, but as a process of mental, moral, religious, and behavioral coaching by the role of a woman in domestic and societal life. In the view of Buton society, the perfect woman is not only beautiful in physical, but in her daily attitude and behavior. Beauty in terms of attitude and deeds was the most appreciated value. The reason is because women are considered to be the most influential people in later household life, both towards their husbands and offspring (Adilia \& Said, 2019). Also, the posuo ritual was also believed to test a girl's chastity (Adilia \& Said, 2019).

Based on Adilia and Said (Adilia and Said, 2019), there were three stages of the ritual procession of posuo implementation are the preparation stage, the procession stage, and the closing stage. The first is the preparatory stage. Before this ritual takes place, the first thing the host does was to prepare everything needed. To begin was consultation with the family, determining the month or day that is considered as good. Once the time has been agreed, the host or the climber announces to the distant family and the surrounding community the activities that will be carried out. The announcement to the family was made to the climber, while the announcement to the community was delivered by indigenous figures. Furthermore, the group and indigenous people contacted bhisa bawine, an elderly woman in the custom or female shaman who would lead and guide the ritual process.

Secondly, the procession stage includes (1) pokunde, where the girls are bathed by bhisa by wetting the girl's hair/shampooing using coconut milk; (2) pebaho, that is, by bathing the girls using water sourced from the spring that has been given prayers; (3) pauncura, which is part of the first session of posuo custom used to strengthen posuo participants; (4) panimpa, which is done by giving a sweep of frankincense smoke to the bodies of the girls who follow the ritual; (5) palego, i.e. by moving the limbs or stretching; (6) padole, i.e. by lay; (7) pasipo, 
i.e. by menyombol; (8) pasuo, i.e. by confinement; (9) bhaliana yimpo, i.e. by changing the position of sleep; (10) landakiana tana, by the evangelist of feet to the ground; and (11) matana posuo, which is the culmination of the event.

Third, the closing stage which was done with the ritual of blessing and the reading of prayer as a form of gratitude to God because this ritual is smooth. After that, proceed with the recovery or cleaning of the suo room specifically. Some feces or fixtures in cages such as white cloths, pillows, mats, and other equipment that are considered disused are disposed off in the river, and some are discarded so that many people do not know. This is aimed at the hope that all the bad things in the girl and the family will disappear along with the discarded filth (Adilia \& Said, 2019).

When it comes to social stratification, the Buton people also know the caste system. The caste system was applied only to the system of government and religious rituals. Bahar LM (Bahar LM, 2014) said that there were five caste systems. First, kaomu or kaumu, which is a nobleman or nobleman who is descended from the descendants of king Wa Kakaa and the King/Sultan is chosen from this group. Secondly, walaka, the ruling elite is descended according to the paternal line of the founding fathers of the Kingdom of Buton (mia patamiana). They hold important positions in the Kingdom such as ministers as well as councils. They are also the one who appoints who will be the next King/Sultan. Third, papara or so-called ordinary people who live in the kadie area (village) and are still independent. They can be considered for certain positions in the kadie region, but have absolutely no path to power in the center. Fourth, babatua (slaves), e.g. people whose lives depend on others or have debts. They can be traded or used as gifts. Fifth, analalaki and limbo are the kaomu and walaka who were demoted for social misconduct and inappropriate behavior by their social status.

\subsection{Ideology Supported By Text of Fiction Related to Traditional Buton Traditions}

The injustice experienced by Johra about the traditional tradition in Wa Ode Wulan Ratna's fiction is a form of gender injustice and patriarchal domination. That is, stereotype and social construction experienced by women is a form of cultural reflection that must be reevaluated. Allegations of female "virginity" are a sensitive issue to be aware of. It is as unique as it seems, but it creates stereotypes in women that can bring unwanted negative things together. For example, if the narrative in this fictional text was developed, perhaps Johra could have been killed by her own father based on accusations caused by this kind of customary tradition. It could also be that the marriage for Johra still exists, if there is a partner equal to his father's social stratification who wants to make Johra his married partner. It could also be that, because of the allegations, Johra locked up her parents out of shame with the results of this tradition, and so on. Therefore, as a good indigenous person, discredited things about women such as delicate and sensitivity of women should be the subject of evaluation for the foreseeable future.

Also, women's struggle to break into the traditional thought of rituals that are judged "kolot" is also a language in this case. As seen in Johra who will be included by her father in this postuo ritual tradition. Johra considers this ritual tradition to limit her wiggle room in determining a partner. Finally, Johra asked for help by making an appointment with La Runduma. Johra's struggles came to fruition, both socially and factually. In social construction, Johra was accused of being no longer a virgin as a result of the rupture of the drum played by her father, only factually, the accusation cannot be proven to be true, Johra is still a virgin. 
The feminist ideology of breaking down Johra's customary tradition in fiction is a form of ideology supported by the author in this cultural product. The ideology has implicitly or expressly represented a mission not to discredit women. Traditions that originally had high educational values should be developed into even better traditions. But if the tradition provides a dominance that tends to bring down the image and dignity of women, who have received less attention, then it should be observed and re-evaluated. It is important by given that patriarchal dominance in society was still dominates. Therefore, all forms that the number of women in all fields must be reviewed. Through critical participation and a good collaborative attitude, it will have an impact to evaluate this dominance into the mission of gender justice and the role of women in all fields and positions.

\section{Conclusions}

Based on the description above, it can be concluded that Indonesian culture is very multicultural. The multiculturalism can be seen in various aspects that participate in each activity. In this fiction by Wa Ode Wulan Ratna, there is a local tradition of Buton people that is full of philosophical and educational values. Posuo's customary tradition is the background of this fictional text, making the conflicts represented even more alive. Conflicts that disgrace women, represented injustices, rituals that discredit women, become the warm talk in this fiction. Through such forms of representation, it implies an ideology that the author's mission was to display. The author advocates that women's roles and positions in various fields should be considered. Her feminist ideology does not make women outperform men, but women can align with men. Various forms of female injustice in public spaces should be considered, whether in the search for a partner or the resulting cultural products, should not dishonor the fate of women. This is the coverted dominance that Wa Ode Wulan Ratna conveys through her fiction.

\section{References}

[1] Adilia, W. F., \& Said, I. M. (2019). Ritual Posuo 'Pingitan' pada Masyarakat Suku Buton: Kajian Semiotika. Jurnal Ilmu Budaya, 7(2), 273-281.

[2] Alifuddin, M. (2015). Siginfikansi Upacara Siklus Posuo dalam Membangun Semesta Keperibadian Remaja Wanita pada Masyarakat Buton. Al-Izzah: Jurnal Hasil-Hasil Penelitian, 10(1), 1-18.

[3] Bahar LM, R. (2014). Akulturasi Budaya Orang Buton. Retrieved from https://lensabudaya-cia2.blogspot.com/2014/04/akulturasi-budaya-orang-buton.html.

[4] Budianta, M. (2006). Budaya, Sejarah, dan Pasar: New Historicism dalam Perkembangan Kritik Sastra. Susastra: Jurnal Ilmu Sastra dan Budaya.

[5] Fariki, L. (2009). Mengapa Perempuan Buton dan Muna Dipingit? Kendari: Komunika.

[6] Gallagher, C., \& Greenblatt, S. (2000). Practicing New Historicism. University of Chicago Press.

[7] Greenblatt, S. (2005). Renaissance Self-Fashioning from More to Shakespeare, new ed. Chicago: University of Chicago Press.

[8] Rampan, K. L. (2013). Antologi Apresiasi Sastra Indonesia Modern. Yogyakarta: 
Narasi. 